\title{
Morphological characterization of canine retrobulbar lymphoma
}

\author{
Natthanet Sritrakoon ${ }^{1}$, Kannika Siripattarapravat ${ }^{2}$, Phudit Maneesaay ${ }^{2}$, Chidozie J. Amuzie ${ }^{3}$ \\ and Aree Thayananuphat,"* \\ ${ }^{1}$ Ophthalmology Unit, Kasetsart University Veterinary Teaching Hospital, Bangkok, 10900, Thailand \\ ${ }^{2}$ Department of Pathology, Faculty of Veterinary Medicine, Kasetsart University, Bangkok, 10900, Thailand \\ ${ }^{3}$ MPI Research, Mattawan, Michigan, 49071, USA \\ ${ }^{4}$ Department of Companion Animal Clinical Sciences, Faculty of Veterinary Medicine, Kasetsart University, \\ Bangkok, 10900, Thailand
}

\begin{abstract}
This report characterized seven cases of canine retrobulbar lymphoma that have been diagnosed during 2008 to 2014 by immunophenotyping of CD3 and Pax5. Classification of lymphoma were performed according to the revised WHO guidelines. Four retrobulbar lymphomas were of T-cell origin, while the others were of B-cell. Out of 7 cases, four subtypes were diagnosed in this study; T-cell-rich large B-cell lymphoma (3/7), T-cell lymphoblastic lymphoma (2/7), peripheral T-cell lymphoma (1/7), and cutaneous nonepitheliotropic lymphoma (1/7). T-cell-rich large B-cell lymphoma was found to be the most frequent subtype found.
\end{abstract}

Keywords: Dog, Immunohistochemistry, Lymphoma, Retrobulbar.

\begin{abstract}
Introduction
Lymphoma is categorized into multicentric (generalized), alimentary, cutaneous, thymic (mediastinal) and extranodal lymphomas (Teske, 1994; Vail et al., 2013). Extranodal lymphoma generally refers to the tumor within tissues such as the eye, central nervous system, bone marrow, bladder, heart and nasal cavity (Fan, 2003; Vail et al., 2013). The term ocular lymphomas generally refers to the tumor at the eyelid, conjunctiva, lacrimal sac, lacrimal gland, orbit and intraocular tissues.

A retrospective study of primary ocular lymphoma in six dogs during 2001-2012 reported three intraocular and three periocular lymphomas (Ota-Kuroki et al., 2014). Among the three periocular lymphomas identified; diffuse large B-cell lymphoma,
\end{abstract} epitheliotropic lymphoma, and lymphoma of natural killer cell type were identified at orbit, conjunctiva, and third eyelid, respectively (Ota-Kuroki et al., 2014). Only six cases of retrobulbar lymphoma in dogs has been reported to date; one case with T-cell-rich large Bcell lymphoma that progressed to a B-cell lymphoma (Aquino et al., 2000), one case with diffuse large B-cell lymphoma (Ota-Kuroki et al., 2014), and the others were not subtype-identified (Hendrix and Gelatt, 2000; Armour et al., 2011).

Classification of lymphoma subtypes can be performed by histopathological examination and immunophenotyping. Such a classification provides an opportunity to select the most appropriate treatment protocol for each dog. A routine processed paraffin- embedded tissue is generally used for immunohistochemistry. Immunohistochemical analysis is routinely used for lymphoma immunophenotyping, and with the current availability of antibody panels for both T-cells and B-cells makes it possible to precisely distinguish each lymphoma subtype. Flow cytometry is as well a tool for immunophenotyping of lymphoid cells (Thalheim et al., 2013); however, the tumor cells need to be individualized for this cell sorting technique, and cannot be evaluated in a morphological context (Lana and Avery, 2009).

Polymerase Chain Reaction for Antigen Receptor Rearrangements (PARR) is another sensitive test and has been suggested for diagnosis of inconclusive cases following routine cytological or histopathological examination (Fan, 2003). The sensitivity of flow cytometry and PARR in comparison with the standard immunohistochemical test, however, is limited to $91 \%$ and 67\%, respectively (Thalheim et al., 2013).

Recently, there has been an increasing availability of antibodies used for immunophenotyping of canine lymphoma (Wilkerson et al., 2005; Willmann et al., 2009; Marconato et al., 2013). In canine, CD3 and PAX5 are acceptable as markers for T-cells and B-cells respectively. CD3 is a T-cell receptor complex which generally uses as a specific T-lymphocyte marker (Olbertz et al., 2013). CD3 is expressed in early thymocytes and throughout the maturation of T-cells (Wilkerson et al., 2005). Pax5 is a nuclear protein in the paired-box containing family of transcription factors, and is known as a B-cell-specific activator protein that 
is extremely specific to B-cell lineages (Willmann et al., 2009). It is upregulated in pro B-cells and downregulated during plasma cell differentiation. Therefore, Pax 5 can be used as a B-cell marker with an exception of plasma cells (Morgan et al., 2013).

Due to limited information on canine retrobulbar lymphoma phenotypes and subtypes, this study aimed to characterize subtypes of retrobulbar lymphoma by using immunophenotype as a diagnostic tool. Specimens were obtained from lymphoma cases diagnosed during 2008-2014 at Kasetsart University Veterinary Teaching Hospital in Bangkok, Thailand. Both histopathological examination and immunohistochemistry for CD3 and Pax5 were performed and the results were integrated with data collected at ophthalmic examination.

\section{Case selection and clinical data}

\section{Materials and Methods}

A total of seven paraffin-embedded specimens were obtained from seven dogs with retrobulbar lymphoma, either tissue-removal by excision or incision, at Kasetsart University Veterinary Teaching Hospital, Bangkok, Thailand, between the period of June 2008 and August 2014.

These specimens were fixed in $10 \%$ neutral buffered formalin or Bouin's solution and were processed according to routine diagnostic histopathology. All paraffin-embedded blocks were kept until the time of this study. Clinical data including sex, breed, age, and ophthalmic signs were reviewed.

\section{Histopathology}

Histopathological characterization of lymphoma was established through a consensus of two veterinary pathologists (one being board-certified by the American College of Veterinary Pathologists, and the other obtained diplomate of Veterinary Pathology from the College of Veterinary Specialties of Thailand) on the basis of detailed nuclear morphology, the number of mitoses per high-power field, and the immunophenotype as have been described by Valli $e t$ al. (2011).

Briefly, nuclear size was characterized as small (if the size is less than $1.5 \mathrm{x}$ of the size of an average red blood cell), intermediate (if the size is approximately $1.5-2 \mathrm{x}$ of the size of an average red blood cell), or large (if the size is more than $2 \mathrm{x}$ of the size of an average red blood cell). The number of mitotic figures was identified according to a total number per a microscopic field of 40x objective lens (high power field-hpf) and was graded as low (if noted 0 to 5 mitotic figures/hpf), medium (if noted 6-10 mitotic figures/hpf) and high (if noted 11 or more mitotic figures/hpf). In addition, immunophenotyping of neoplastic cells was assessed based upon the proportion of CD3 membrane and/or cytoplasmic labeling and the proportion of Pax5 nuclear labeling.

\section{Immunohistochemistry}

The specimens were sectioned at $4 \mu \mathrm{m}$ thickness; one section was stained with $\mathrm{H} \& \mathrm{E}$ using a standard protocol, and the other was placed on a positively charged slide for immunohistochemical analysis. For labeling T-cells, a polyclonal rabbit anti-human CD3 antibody (Dako Denmark A/S, Glostrup, Denmark) was used. A monoclonal mouse Pax-5 antibody (Clone $1 \mathrm{EW}$, Novocastra ${ }^{\mathrm{TM}}$, Newcastle upon Tyne, UK) was used for B-cell labeling. In our study, the availability of cross-reactive antibodies for canine tissues was a major challenge for immunohistochemistry, and the selection of specific primary antibodies was critical for proper phenotyping. We have tested several commercially available antibodies, and only ones listed above can be successfully used. Normal canine lymph nodes were used as positive control. A negative control was accomplished by using homologous nonimmunized sera for replacement of the primary antibodies.

Immunohistochemistry for CD3 was performed using a multistep protocol. First, the sections were deparaffinized by heating the slides in an oven at $50^{\circ} \mathrm{C}$ for 60 minutes, rehydrated by a series of washes with xylene, ethanol, distilled water and, finally, washed with running tap water. Antigen retrieval was done in citrate buffer ( $\mathrm{pH} 6.0)$ by boiling specimens in a $720 \mathrm{w}-$ microwave oven for 16 minutes. Slides were allowed to cool down for 30 minutes and then washed with Trisbuffered saline (TBS). The endogenous peroxidase was inactivated by incubating slides in 3\% hydrogen peroxide for 15 minutes. Slides were washed with TBS and blocked with $5 \%$ bovine serum albumin in TBS for 30 minutes. The specimens were incubated with primary antibody for 60 minutes in a humidified chamber at $37^{\circ} \mathrm{C}$ and washed with TBS. The secondary HRP-conjugated anti-rabbit antibody (Dako Envision $^{\mathrm{TM}}+/ \mathrm{HRP}$ kits) was applied. Slides were incubated for 45 minutes in a humidified chamber at $37^{\circ} \mathrm{C}$ and then washed with TBS. Diaminobenzidine chromogen was added to the specimens, which were incubated at room temperature for 3-5 minutes. The sections were counterstained with Mayer's hematoxylin.

Immunohistochemistry for B-cells was performed on the autostainer, Leica Microsystems Bond maX System (Leica Microsystems, Bannockburn, IL), according to the manufacturer's recommendation. Briefly, sections were incubated with Bond Dewax Solution at $72^{\circ} \mathrm{C}$. Antigen retrieval was performed in Bond Epitope Retrieval Solution 2 at $100^{\circ} \mathrm{C}$. A Bond Polymer Refine Detection kit was used for an indirect immunoperoxidase assay. Primary antibody was applied at room temperature, and then the specimen was rinsed with the Bond Wash Solution. Blocking with 3\% hydrogen peroxide was applied and slides were then rinsed with Bond Wash Solution. Next, Post 
Primary Polymer was applied and then the slides were rinsed with Bond Wash Solution. Subsequently, Polymer Poly-HRP IgG was applied, then being rinsed with Bond Wash Solution and with deionized water. Diaminobenzidine chromogen was applied, and slides were rinsed in deionized water. Finally, the sections were counterstained with Mayer's hematoxylin.

\section{Results}

\section{Clinical presentation}

Relevant clinical information of all cases was summarized in Table 1. Orbital computed tomography scans were used in all dogs to evaluate the extent of the disease. The median age of dogs with retrobulbar lymphoma was 11 years (range 5-13 years). Retrobulbar lymphoma was found in 6 males $(85.7 \%)$ and 1 female (14.3\%). Four dogs were crossbreeds (57\%) and the other three were Chow Chow, Shih Tzu, and Labrador Retriever. Globe displacement was the only clinical sign which all owners complained. Ophthalmic examination revealed exophthalmos (7/7), third eyelid protrusion (7/7), corneal ulcer (4/7), chemosis (3/7) and secondary glaucoma (2/7).

\section{Histopathological characterization of retrobulbar lymphoma}

Three retrobulbar lymphomas were immunopositive for Pax5, while the other four cases were positive for CD3, which were characterized as B-cell and T-cell lymphoma, respectively. According to WHO criteria, 4 subtypes of canine retrobulbar lymphoma were identified in this study, including; T-cell-rich large Bcell lymphoma (3/7), T-cell lymphoblastic lymphoma (2/7), peripheral T-cell lymphoma (1/7), and cutaneous nonepitheliotropic lymphoma (1/7) (summarized in Table 1).

The most common was T-cell-rich large B-cell lymphoma subtype. This subtype had mixed cell types, which the majority were small reactive $\mathrm{T}$ lymphocytes (small cells with compact hyperchromatic nuclei and shallow nuclear indentation), and mild to moderate numbers of large cells of B-cell origin (cells with large vesicular nuclei and prominent nucleoli). T-cell-rich large B-cell lymphoma was primarily positive for Pax5 and had infiltrative scattered CD3 positive T-cells (Fig. $1)$. One of these 3 cases had concurrent masses in abdomen.

T-cell lymphoblastic lymphoma, two cases, were identified in this study. Neoplastic cells had scant cytoplasm and round or convoluted nuclei. Mitotic rate was high. Apoptotic bodies were frequently seen. These tumors showed what so called "starry sky" and many tangible-body macrophages. The neoplastic cells were CD3 positive and Pax5 negative (Fig. 2). One of these 2 cases had a generalized skin masses.

One case of peripheral T-cell lymphoma was characterized. There were diffuse mixed lymphoid cells with variable sizes and often associated with vascular proliferation and mixed inflammatory cell infiltration. In general, this tumor can also be classified as a mixed lymphoid or a mixed inflammatory type, and the latter description is matched with this case. This subtype of tumor was markedly vascularized and had invasive behavior. In addition, a concurrent mass was noted at a masseter muscle, suggesting a distant metastasis. The neoplastic cells were CD3 positive and Pax5 negative (Fig. 3).

One case of cutaneous nonepitheliotropic lymphoma was characterized. There were thickening and ulceration of skin as a result of massive proliferation of lymphoid cells in dermis. This subtype of tumor comprised small lymphocytes with abundant and clear cytoplasm. The neoplastic cells were CD3 positive and Pax5 negative (Fig. 4). No concurrent mass was noted.

\section{Survival time}

Survival time was calculated from the time of diagnosis to death from any cause or time of last follow-up. The minimal survival time of retrobulbar lymphoma dogs was 2 months 2 weeks and the maximal survival time was 2 years 5 months. Four dogs were dead from metastatic lymphoma whereas two dogs were dead from other causes (Table 1).

\section{Discussion}

Retrobulbar tumors occur rarely in dogs and cats, they represent $4 \%$ of all cancers (Gilger et al., 1992). The study of retrobulbar tumors reveal that most of them were characterized as malignant; $75 \%$ of tumors in dogs and $88 \%$ in cats (Attali-Soussay et al., 2001), and none of them were diagnosed as lymphoma, suggesting that retrobulbar lymphoma is quite rare. To the best of our knowledge, only six cases of canine retrobulbar lymphoma were reported and subtyping were done in 2 cases (summarized in Table 1, Aquino et al., 2000; Hendrix and Gelatt, 2000; Armour et al., 2011; OtaKuroki et al., 2014). In this study, we reported 7 cases and that provided additional information including subtype characterization of lymphoma in this certain region of the body.

All cases showed severe ocular lesions at the time of admission to the hospital and surgical removal was performed for further diagnosis as well as treatment. Exenteration is typically recommended as palliative therapy for primary orbital neoplasms, particularly in cases where the associated eye is blind or painful owing to the effects of exposure (Conceicao et al., 2010), and due to the location and invasiveness of the tumors, in most cases (6/7), exenteration was performed. In one of these six cases, lateral orbitotomy was primarily done but the tumor relapsed at 4 months afterward and that exenteration was eventually performed. Unfortunately, we lost contact with the only case the owner denied exenteration and incisional surgery was done, so that the outcome could not be followed accordingly. 
Table 1. Signalment, phenotypes and subtype classification of retrobulbar lymphoma in dogs.

\begin{tabular}{|c|c|c|c|c|c|c|c|c|}
\hline Case & Sex & Breed & $\begin{array}{l}\text { Age } \\
\text { (yrs) }\end{array}$ & Eye & Phenotypes & $\begin{array}{c}\text { Classification of } \\
\text { lymphoma subtypes }\end{array}$ & Concurrent masses & Survival time \\
\hline 1 & M & Chow Chow & 9 & OS & T-cell & $\begin{array}{l}\text { T-cell lymphoblastic } \\
\text { lymphoma }\end{array}$ & - & N/A \\
\hline 2 & $\mathrm{~F}$ & Cross & 12 & OS & T-cell & $\begin{array}{l}\text { T-cell lymphoblastic } \\
\text { lymphoma }\end{array}$ & $\begin{array}{l}\text { Generalized skin } \\
\text { masses }\end{array}$ & $\begin{array}{l}2 \text { months } 2 \text { weeks } \\
\text { (Dead from metastatic } \\
\text { lymphoma) }\end{array}$ \\
\hline 3 & M & Cross & 12 & OD & T-cell & $\begin{array}{l}\text { Cutaneous } \\
\text { nonepitheliotropic } \\
\text { lymphoma }\end{array}$ & - & $\begin{array}{l}3 \text { months } \\
\text { (Dead from metastatic } \\
\text { lymphoma) }\end{array}$ \\
\hline 4 & M & $\begin{array}{l}\text { Labrador } \\
\text { Retriever }\end{array}$ & 5 & OD & T-cell & $\begin{array}{l}\text { Peripheral T-cell } \\
\text { lymphoma }\end{array}$ & $\begin{array}{l}\text { Mass under masseter } \\
\text { muscle (biopsy: } \\
\text { lymphoma) }\end{array}$ & $\begin{array}{l}5 \text { months } \\
\text { (Dead from metastatic } \\
\text { lymphoma) }\end{array}$ \\
\hline 5 & M & Cross & 11 & OS & B-cell & $\begin{array}{l}\text { T-cell-rich large B- } \\
\text { cell lymphoma }\end{array}$ & N/A & $\begin{array}{l}4 \text { months } \\
\text { (Dead from metastatic } \\
\text { lymphoma) }\end{array}$ \\
\hline 6 & M & Shih Tzu & 10 & OD & B-cell & $\begin{array}{l}\text { T-cell-rich large B- } \\
\text { cell lymphoma }\end{array}$ & - & $\begin{array}{l}2 \text { years } 5 \text { months } \\
\text { (Dead from Babesiosis) }\end{array}$ \\
\hline 7 & M & Cross & 13 & OS & B-cell & $\begin{array}{l}\text { T-cell-rich large B- } \\
\text { cell lymphoma }\end{array}$ & $\begin{array}{l}\text { Heterogenous mass at } \\
\text { spleen }\end{array}$ & $\begin{array}{l}1 \text { year } 11 \text { months } \\
\text { (Dead from accident) }\end{array}$ \\
\hline Ref. 1 & $\mathrm{~F}$ & $\begin{array}{l}\text { Shetland } \\
\text { Sheepdog }\end{array}$ & 11 & OD & B-cell & $\begin{array}{l}\text { T-cell-rich large B- } \\
\text { cell lymphoma }\end{array}$ & $\begin{array}{l}\text { Liver, mesenteric } \\
\text { lymph node, and } \\
\text { jejunum }\end{array}$ & $\begin{array}{l}6 \text { months } \\
\text { (Euthanatized due to } \\
\text { progressive metastatic } \\
\text { lymphoma) }\end{array}$ \\
\hline Ref. 2 & M & Cross & 13 & OS & B-cell & $\begin{array}{l}\text { Diffuse large B-cell } \\
\text { lymphoma }\end{array}$ & - & N/A \\
\hline
\end{tabular}

(OD): right eye; (OS): left eye; (OU): both eyes; (M): male; (F): female; (Ref. 1): Aquino et al., 2000; (Ref. 2): Ota-Kuroki et al., 2014; (n/a): not applicable.

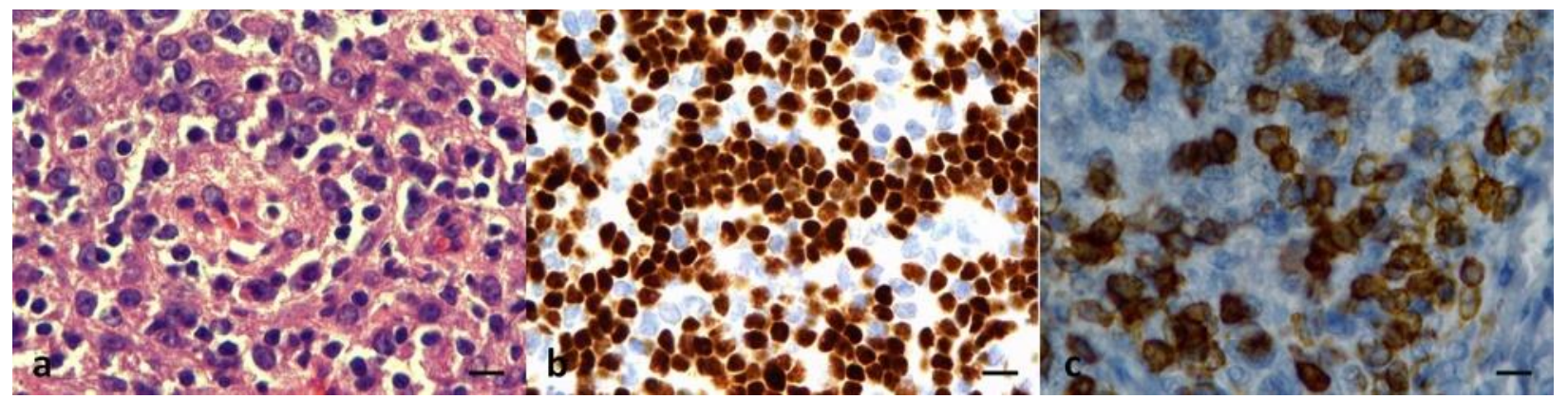

Fig. 1. Dog, retrobulbar mass, T-cell-rich large B-cell lymphoma. (a) Retrobulbar tissue is massive infiltrated with heterogenous population of cells. Large neoplastic cells with round to oval hyperchromatic nuclei and prominent multiple nucleoli and variable cytoplasm and small lymphocytes. (b) Numerous neoplatic cells are positive for Pax5. (c) Large neoplastic cells are negative for CD3 while some small lymphocytes stain strongly positive for CD3. Bar, $20 \mu \mathrm{m}$.

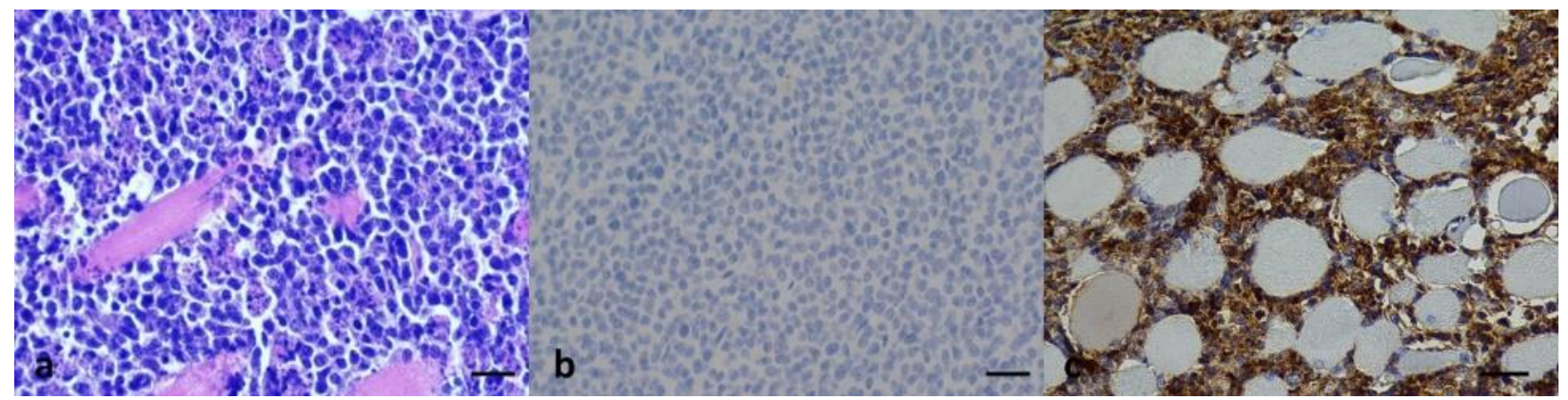

Fig. 2. Dog, retrobulbar mass, T-cell lymphoblastic lymphoma. (a) Neoplastic cells are intermediate size with densely stained, indistinct nucleolar nuclei and scant cytoplasm. "Starry-sky" appearance due to numerous tangible-body macrophages is noted. (b) Neoplastic cells are negative immunostaining for Pax5. (c) Neoplastic T-cells are densely positive for CD3. Bar, $20 \mu \mathrm{m}$. 


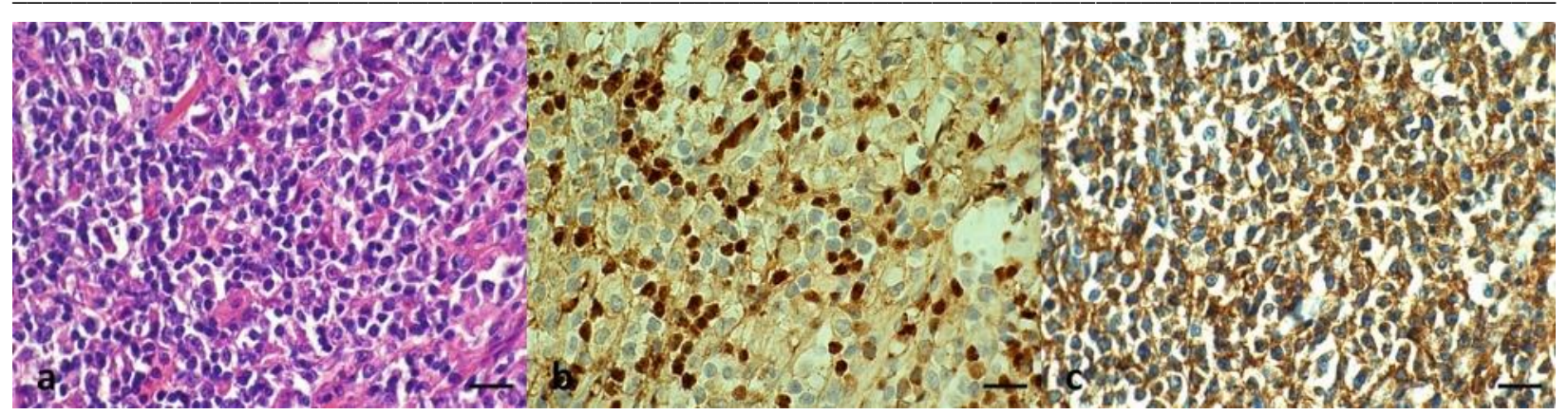

Fig. 3. Dog, retrobulbar mass, peripheral T-cell lymphoma. (a) Histopathological finding of intermediate and large lymphoid cells mixed with plasma cells, macrophages and multinucleated giant cells. Some small necrotic tissue are also seen. (b) Some small lymphocytes are positively stained with Pax5. (c) Numerous neoplastic cells are positive for CD3. Bar, $20 \mu \mathrm{m}$.

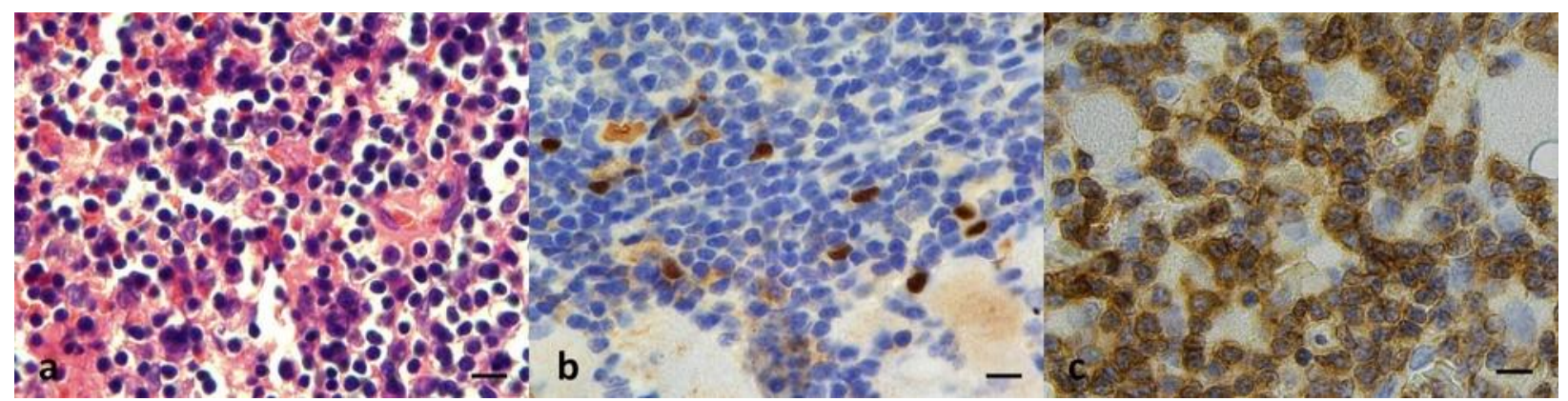

Fig. 4. Dog, retrobulbar mass, cutaneous nonepitheliotropic lymphoma. (a) Retrobulbar tissue are infiltrated with small neoplastic cells. Cells have small indented hyperchromatic nuclei, indistinct nucleoli and abundant, clear cytoplasm. (b) Neoplastic cells are negative for Pax5. (c) Neoplastic cells are positive for CD3. Bar, $20 \mu \mathrm{m}$.

It is generally accepted that cytological examination is very useful when diagnosing round cell tumor, and in this case lymphoma (Gilger et al., 1992), and cytologic analysis of an orbital mass suggests the presence of a potentially resectable benign primary orbital neoplasm (Conceicao et al., 2010). We propose that submitting a specimen for cytopathological diagnosis is useful for decision making and surgical plan of these rare tumor cases, and if lymphoma is diagnosed with painful, invasive, or infiltrative orbital masses with blind eye such as these cases, exenteration can be initiated as palliative treatment. If preservation of orbit function is a choice, treatment plan including adjuvant chemotherapy or radiotherapy should be implemented because complete resection of the retrobulbar mass is difficult and local relapse rate after surgery is high (Eckardt et al., 2013; Tsen et al., 2015).

In general, B-cell phenotype tended to be the predominant phenotype in ocular lymphoma (OtaKuroki et al., 2014). However, with regard to the locations of the masses, the retrobulbar region - in this study, T-cell phenotype (4/7) was slightly overrepresented than one of B-cell (3/7). Although diffuse large B-cell lymphoma was reported to be the most common subtype of canine lymphoma (Valli et al., 2011), concerning different anatomic location, Tcell-rich large B-cell lymphoma appeared to be more common subtype of retrobulbar area in our and previously studies (Aquino et al., 2000). Interestingly, none of the seven retrobulbar lymphomas in this study were diffuse large B-cell lymphoma as previously reported in one dog (Ota-Kuroki et al., 2014). Subtypes identified herein and other related studies were randomized (Aquino et al., 2000; Ota-Kuroki et al., 2014). This study, for the first time, has demonstrated that T-cell lymphoblastic lymphoma, cutaneous nonepitheliotropic lymphoma and peripheral T-cell lymphoma subtypes were also found at the retrobulbar location (Aquino et al., 2000; Ota-Kuroki et al., 2014). Both T-cell and B-cell phenotypes were presented in our cases. In accordance with previous report that Tcell immunophenotype had a much more unfavourable prognosis than did B-cell immunophenotype (Teske, 1994), we also noted that cases with T-cell lymphoma have survival time less than those of B-cell. Due to small number of cases found and variation in subtypes presented, survival time for each case was varied.

The most common canine primary orbital tumors are osteosarcomas, mast cell tumors, reticulum cell sarcomas, fibrosarcomas, and neurofibrosarcomas (Kern, 1985). According to an anatomical structure of retrobulbar region, no lymphoid tissue is recognized (van der Gaag, 1998; Grahn and Peiffer, 2013), and thus lymphoma is often noted as a secondary tumor (Grahn and Peiffer, 2013). In 3 cases (3/6, one case was lost), there were concurrent masses at other locations 
which a secondary tumor could be concluded. In other 3 cases investigated, we did not identify any tumor and all lymph nodes appeared to be normal in size. It is left to be elucidated how these tumors arouse primarily at the retrobulbar area.

In conclusion, we reported a series of 7 canine retrobulbar lymphoma cases which subtypes were identified by using histopathological and immunohistochemical analysis. Subtypes of lymphoma that can be found in this region, from our and other studies (Aquino et al., 2000; Ota-Kuroki et al., 2014) included T-cell-rich large B-cell lymphoma, T-cell lymphoblastic lymphoma, cutaneous nonepitheliotropic lymphoma, peripheral T-cell lymphoma subtypes and diffuse large B-cell lymphoma. The classification of ocular lymphoma subtypes provides information essential for prognosis and treatment plans, which ultimately will help to prolong the overall survival time of the patients.

\section{Acknowledgments}

The author would like to thank Intervet Research Fund for the financial support. The author would like to thank Pakawadee Pongket and Koson Intarasut for their advice in laboratory practice and to thank Natapong Kraiwong for figure illustration.

\section{Conflict of interest}

The authors declare that there is no conflict of interest.

\section{References}

Aquino, S.M., Hamor, R.E., Valli, V.E., Kitchell, B.E., Tunev, S.S., Bailey, K.L. and Ehrhart, E.J. 2000. Progression of an orbital T-cell rich B-cell lymphoma to a B-cell lymphoma in a dog. Vet. Pathol. 37, 465-469.

Armour, M.D., Broome, M., Dell'Anna, G., Blades, N.J. and Esson, D.W. 2011. A review of orbital and intracranial magnetic resonance imaging in 79 canine and 13 feline patients (2004-2010). Vet. Ophthalmol. 14, 215-226.

Attali-Soussay, K., Jegou, J. and Clerc, B. 2001. Retrobulbar tumors in dogs and cats: 25 cases. Vet. Ophthalmol. 4, 19-27.

Conceicao, L.F., Ribeiro, A.P., Piso, D.Y.T. and Laus, J.L. 2010. Considerations about ocular neoplasia of dogs and cats. Ciênc. Rural. 40, 2235-2242.

Eckardt, A.M., Lemound, J., Rana, M. and Gellrich, N. 2013. Orbital lymphoma: diagnostic approach and treatment outcome. World J. Surg. Oncol. 11, 73. doi: 10.1186/1477-7819-11-73.

Fan, T.M. 2003. Lymphoma updates. Vet. Clin. North Am. Small Anim. Pract. 33, 455-471.

Gilger, B.C., McLaughlin, S.A., Whitley, R.D. and Wright, J.C. 1992. Orbital neoplasms in cats: 21 cases. J. Am. Vet. Med. Assoc. 201, 1083-1086.

Grahn, B.H. and Peiffer, R.L. 2013. Veterinary Ophthalmic Pathology. In Veterinary
Ophthalmology, $5^{\text {th }}$ edn, Eds., Gelatt, K.N., Gilger, B.C. and Kern, T.J. Iowa: John Wiley \& Son, pp: 435-523.

Hendrix, D.V.H. and Gelatt, K.N. 2000. Diagnosis, treatment and outcome of orbital neoplasia in dogs: a retrospective study of 44 cases. J. Small Anim. Pract. 41, 105-108.

Kern, T.J. 1985. Orbital neoplasia in 23 dogs. J. Am. Vet. Med. Assoc. 186, 489-491.

Lana, S.E. and Avery, A. 2009. Canine lymphoma. In Kirk's Current Veterinary Therapy XIV, Ed., Bonagura, J. St. Louis: Saunders Elsevier, pp: 336339.

Marconato, L., Gelain, M.E. and Comazzi, S. 2013. Invited review: The dog as a possible animal model for human non-Hodgkin lymphoma: a review. Hematol. Oncol. 31, 1-9.

Morgan, E.A., Pozdnyakova, O., Nascimento, A.F. and Hirsch, M.S. 2013. Pax8 and Pax5 are differentially expressed in B-cell and T-cell lymphomas. Histopathology 62, 406-413.

Olbertz, L., Lima, L., Langohr, I., Werner, J., Teixeira, L. and Montiani-Ferreira, F. 2013. Case report: Supposed primary conjunctival lymphoma in a dog. Vet. Ophthalmol. 16, 100-104.

Ota-Kuroki, J., Ragsdale, J.M., Bhupinder, B., Wakamatsu, N. and Kuroki, K. 2014. Intraocular and periocular lymphoma in dogs and cats: a retrospective review of 21 cases (2001-2012). Vet. Ophthalmol. 17, 389-396.

Teske, E. 1994. Canine malignant lymphoma: A review and comparison with human non-Hodgkin's lymphoma. Vet. Quart. 16, 209-219.

Thalheim, L., Williams, L.E., Borst, L.B., Fogle, J.E. and Suter, S.E. 2013. Lymphoma immunophenotype of dogs determined by immunohistochemistry, flow cytometry, and polymerase chain reaction for antigen receptor rearrangements. J. Vet. Intern. Med. 27, 1509-1516.

Tsen, C., Lin, M., Bee, Y., Chen, J., Kuo, N. and Sheu, S. 2015. Ocular adnexal lymphoma: Five case reports and a literature review. Taiwan J. Ophthalmol. 5, 99-102.

Vail, D.M., Pinkerton, M.E. and Young, K.M. 2013. Hematopoietic Tumors. In Withrow and MacEwen's Small Animal Clinical Oncology, $5^{\text {th }}$ edn., Eds., Withrow, S.J., Vail, D.M. and Page, R.L. Missouri: Saunders Elsevier, pp: 608-678.

Valli, V.E., Myint, M.S., Barthel, A., Bienzle, D., Caswell, J., Colbatzky, F., Durham, A., Ehrhart, E.J., Johnson, Y., Jones, C., Kiupel, M., Labella, P., Lester, S., Miller, M., Moore, P., Moroff, S., Roccabianca, P., Ramos-Vara, J., Ross, A., Scase, T., Tvedten, H. and Vernau, W. 2011. Classification of canine malignant lymphomas according to the World Health Organization criteria. Vet. Pathol. 48, 
198-211.

van der Gaag, R. 1988. Immunological responses in the eyelid and orbit. Eye 2, 158-163.

Wilkerson, M.J., Dolce, K., Koopman, T., Shuman, W., Chun, R., Garrett, L., Barber, L. and Avery, A. 2005. Lineage differentiation of canine lymphoma/leukemias and aberrant expression of CD molecules. Vet. Immunol. Immunopathol. 106,
179-196.

Willmann, M., Mullauer, L., Guija de Arespacochaga, A., Reifinger, M., Mosberger, I. and Thalhammer, J.G. 2009. Pax5 immunostaining in paraffinembedded sections of canine non-Hodgkin lymphoma: a novel canine pan pre-B- and B-cell marker. Vet. Immunol. Immunopathol. 128, 359365 . 